\title{
Nova Etapa
}

$O$

Serviço de Documentação do D.A.S.P., na fase em que ora ingressa com a nova administração, está empenhado em atingir a todos os objetivos contidos nas diretrizes gerais que nortearam a sua criação. Mas não só. A par do prosseguimento de obras e iniciativas cuja valia se estampa na simples enunciação, há que mencionar, agora, um esfôrço afincado e atento no sentido de novos, mais amplos empreendimentos. Está nesse caso, para citar um exemplo, a articulação em curso com o National Archives, de Washington, a fim de promover-se a edição de volumes referentes à técnica geral de arquivos.

Quanto aos Cadernos de Administração, continua a editá-los o Serviço de Documentação, sob o critério impositivo das próprias características que thes dita a simples denominação. Semelhantemente, dará curso o Serviço de Documentação à História Administrativa do Brasil, cujos primeiros volumes, em número de três, se acham já agora em vias de lançamento. Ainda o mesmo critério rêco e lúcido dirigirá a tiragem com todo o apuro gráfico de separatas desta Revista que mereçam o destaque especial, pelo valor e utilidade. Encontram-se por igual em fase de lançamento dois trabalhos de pesquisa estatística e análise social, a saber "Os Vencimentos no Serviço Público Federal" e "A Mulher no Serviço Público". Trata-se de volumes iniciais de uma série a elaborar-se sob o tnesmo critério objetivo, prático, atual.

Não se carece pois dar ênfase ao aspecto seletivo, o qual deve configurar, iniludivelmente, as publicações em pauta, para que estas não se acumulem quantitativamente, sem qualquer preocupação qualitativa. Estarão em curso assim publicações de todo o in- 
terêsse administrativo, já pelo caráter documental de que se vistam, já pelas idéias que veiculem.

Entre elas contar-se-ão por certo as trađuções de livros estrangeiros de interêsse e valia, as quais mereçam acolhida pela qualidade de quem das mesmas fôr responsável.

Por outra, parte, o Serviço de Documentação, mediante ação articulada, encetará publicações de interêsse específico das divisões Jo D.A.S.P., como sejam Orçamento e Orǵanização, Pessoal, Seleção e Aperfeiçoamento e Cursos de Administração, além dos diversos outros setores departamentais. Aí se inclui também, para dat mais um exemplo, a separata do relatório do Escritório Técnico da Universidade do Brasil (E.T.U.B. ), a ser tirada em seguida à publicação inicial pela "Revista do Serviço Público".

Antes que um programa, o acima anunciado representa mero esfôrço exigido pelo dever, que pesa sôbre cada setor da administração, de alcançar as finalidades para as quais foi criado. 